\title{
Stone pine (Pinus pinea) growth and cone yield as a function of planting density in Chile
}

\author{
Crecimiento y producción de piñas de pino piñonero (Pinus pinea) en Chile \\ en función de la densidad de plantación
}

\author{
Verónica Loewe Muñoz ${ }^{\text {a*}}$, Rodrigo Del Río a , Mónica Balzarini ${ }^{\text {b }}$ \\ Corresponding author: ${ }^{a}$ Chilean Forest Institute (INFOR), Metropolitan Office, Sucre 2397, Santiago, Chile, \\ tel.: 56-2-23667111, vloewe@infor.cl \\ ${ }^{\mathrm{b}}$ Universidad Nacional de Córdoba, College of Agriculture, CONICET Biometry Unit, Córdoba, Argentina.
}

\begin{abstract}
SUMMARY
Pinus pinea (stone pine) is an important species for its delicious seeds -the pine nuts-, the most expensive dry fruit worldwide. In native habitats, planting density is a key silvicultural tool in this highly heliophile species due to its impact on growth and cone yield. In Chile, the densities of adult plantations are medium and high. The goal of this study was to assess the impact of density on growth and cone yield in established plantations. Thirty plantations, 15 at high density $\left(1,667\right.$ trees ha $\left.{ }^{-1}\right)$ and 15 at medium density $(500$ trees $\left.\mathrm{ha}^{-1}\right)$, were matched into 15 pairs of similar plantations regarding age and site characteristics. Planting density had a significant impact on $P$. pinea growth and cone yield. The medium density was associated with $46 \%$ higher diameter-at-breast-height (DBH) and 2.8 times higher cone yield than those presented by a high-density plantation scheme. However, at 500 trees ha $^{-1}$, average tree height might turn cone harvesting difficult and expensive. In humid areas (Chilean South macrozone), the medium planting density had a more important effect on cone yield than on growth. Our study confirms previous research in stone pine native habitats and highlights the need to find an optimum planting density to favor cone yield and harvest.
\end{abstract}

Key words: vegetative growth, cone yield, intensive silviculture, plantation spacing.

\section{RESUMEN}

El pino piñonero (Pinus pinea) es una especie importante por sus deliciosas semillas (piñones), el fruto seco más caro del mundo. En su hábitat nativo, la densidad de plantación es una decisión silvicultural clave en esta especie heliófila debido a su impacto en el crecimiento y producción de piñas. En Chile, las densidades de plantaciones adultas son medias y altas. El objetivo de este estudio fue evaluar el impacto de la densidad en el crecimiento y producción de piñas en plantaciones establecidas. Treinta plantaciones, 15 con alta densidad (1.667 árboles ha ${ }^{-1}$ y 15 con densidad media (500 árboles ha ${ }^{-1}$ ) se agruparon en pares de plantaciones de similar edad y características del sitio. La densidad de plantación tuvo un impacto significativo en el crecimiento y producción de piñas de $P$. pinea. La densidad media estuvo asociada con $46 \%$ mayor diámetro a la altura del pecho y 2,8 veces mayor producción de piñas que en el esquema de alta densidad. No obstante, en la densidad de 500 árboles ha $^{-1}$, la altura media puede dificultar y encarecer la cosecha de piñas. En áreas húmedas (macrozona sur de Chile), la densidad media de plantación tuvo un efecto mayor en la producción de piñas que en el crecimiento. Este estudio confirma investigaciones previas realizadas en hábitats nativos del pino piñonero y subraya la necesidad de encontrar una densidad de plantación óptima para favorecer la producción de piñas y la cosecha.

Palabras clave: crecimiento vegetativo, producción de piñas, silvicultura intensiva, efecto del espaciamiento.

\section{INTRODUCTION}

Pinus pinea Linneo (stone pine) is important for its delicious and expensive seeds, the pine nuts. The species has shown a good adaptation in Chile (Loewe et al. 2016, 2017a), where it is considered an emerging fruit crop, with over 2,000 hectares planted in the last years. In Argentina, the species has been planted mainly in coastal areas for dune stabilization, covering about 300 hectares. As a pioneer species, it is highly heliophile and very sensitive to intra- or interspecific competition, which determines its crown shape. Therefore, planting density is an important factor to be considered for maximizing cone production (Piqué 2013). On the other hand, height growth can be controlled by pruning or using an adequate spacing to maintain the crown low and large enough to facilitate harvesting. Moreover, mechanized cone harvesting is easier and significantly more cost-effective in sparse than in denser stands, where manual harvesting may be required (Pasalodos-Tato et al. 2016).

Information about the effects of stand density is determinant for a good planting design, particularly in intensive 
silviculture; the effects on cone yield were studied for the species in the main producer countries (Piqué et al. 2011, Moreno-Fernandez et al. 2013). The desirable final density in plantations oriented to cone production was determined in 100 trees $\mathrm{ha}^{-1}\left(10^{\prime} 10 \mathrm{~m}\right)$ in Portugal (Correia et al. 2010) and Spain (Mutke et al. 2012); density was found to boost tree cone production (Montero et al. 2008)

Pinus pinea is a promising species for intensive silviculture in Chile and Argentina in a context of climate change due to its low hydric requirement (Loewe et al. 2020). Therefore, this paper addresses the key question of the impact of medium and high-density schemes on cone yield in adult plantations. This study is complementary to a previous work by Loewe et al. (2019), which analyzed the initial impact of low-density schemes (204 to 400 trees $\mathrm{ha}^{-1}$ ) on growth and fruiting of young plantations, by including adult plantations established and managed at higher density. In fact, $P$. pinea plantations established with non-productive purposes (erosion control and cattle shadowing) have medium density (500 trees ha-1, $4 \times 5 \mathrm{~m}$ ) to high density (1,667 trees ha-1, $2 \times 3 \mathrm{~m}$ or even higher), a pattern that could be inappropriate for cone production, and that also induces excessive height growth (Loewe and Delard 2016).

Management techniques for $P$. pinea cropping for cone production were proposed (Loewe et al. 2017b), including techniques commonly used in horticulture, such as fertilization and irrigation. Considering that the vegetative growth of the species across the species macrozones in Chile (Loewe et al. 2015) is higher than in its native area, we hypothesize that the highest density reduces diameter growth and cone yield. The main goal of this study is to evaluate the effect of medium and high $P$. pinea planting density on (1) diameter and height growth, and (2) cone yield across three macrozones of Chile. This information may be useful for the establishment of new plantations and management of already established ones.

\section{METHODS}

Observational study. Over the past decade, given the interest in P. pinea cultivation, the Chilean Forest Institute (INFOR) has conducted a long-term, large-scale national research to gather data from Chile, covering a wide area between Coquimbo $\left(30.8 \mathrm{~S}^{\circ}\right)$ and Araucanía $\left(39.0 \mathrm{~S}^{\circ}\right)$ Regions. Inventories of $P$. pinea populations were performed, including plantations established for commercial and environmental purposes. A survey was conducted in 41 plantations, where all $P$. pinea trees were measured for diameter-at-breast-height (DBH) at $130 \mathrm{~cm}$ above the ground with a caliper, and height with a hypsometer. Annual growth in DBH and height was estimated by dividing the measured DBH and height by the plantation age. All 3-year-old mature cones per tree were counted from a standing position on the ground. However, given the high density and tree sizes, cone counting might have been bia- sed, and, consequently, the true cone number may have been underestimated, since the upper third of the crown was not always totally visible from the standing position. Cone yield was estimated as the total cone production per hectare. Plantation age, as reported by the owners, ranged from 12 to 50 years. According to Loewe et al. (2016), plantations aged 8 years and older are considered productive in Chile.

A total of 30 plantations from the above-described survey (see their description in table 1) were matched in 15 pairs of similar age and site characteristics and different planting density: high density (on average 1,667 trees ha ${ }^{-1}$ ) and medium density (on average 500 trees $\mathrm{ha}^{-1}$ ). Considering the regional differences in cone yield reported by Calama et al. (2016), the 15 pairs were distributed across the three macrozones delimited for the species in Chile by Loewe et al. (2015) (figure 1).

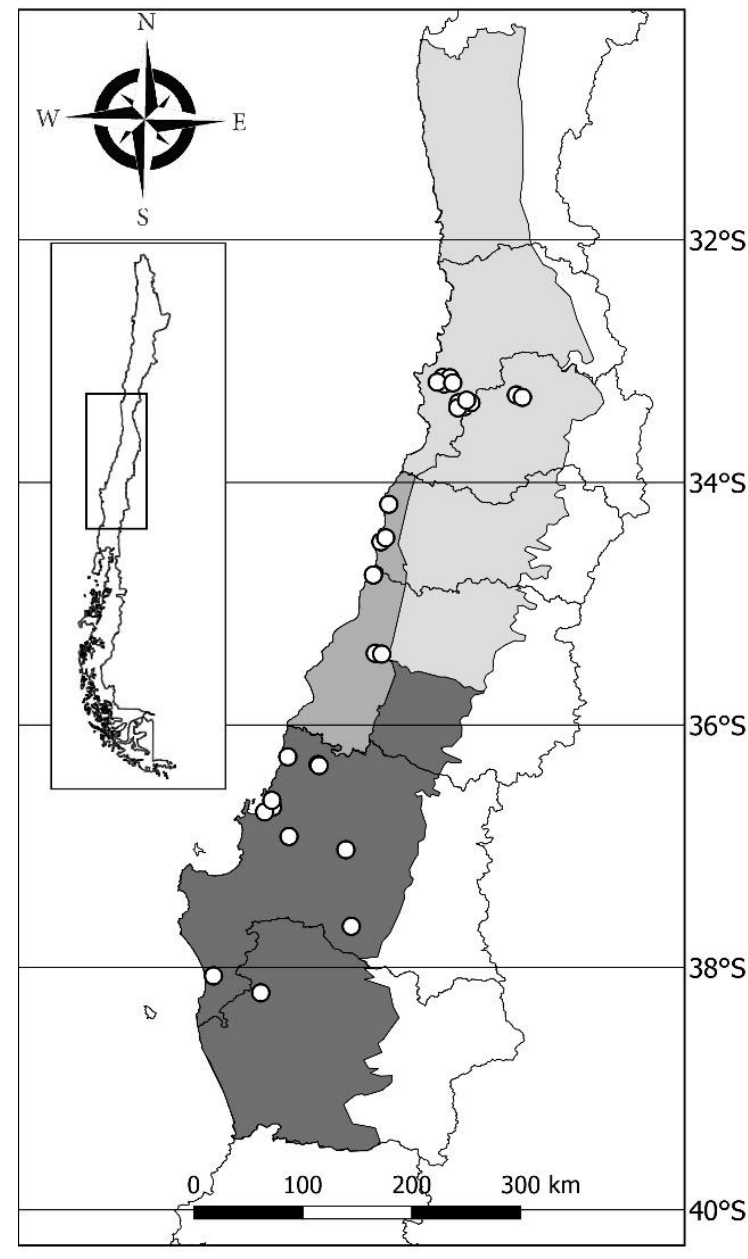

Figure 1. Pinus pinea plantation sites included in the study in Chile. Light grey: North, Grey: Dry Coast, Dark grey: South macrozones, as described in Loewe et al. (2015).

Distribución de plantaciones de Pinus pinea incluidas en el estudio en Chile. Macrozonas Norte: gris claro; Secano costero: gris; Sur: gris oscuro. 
Table 1. Pairs of similar Pinus pinea plantations with a different number of trees per hectare.

Pares de plantaciones de Pinus pinea con diferente cantidad de árboles por hectárea.

\begin{tabular}{|c|c|c|c|c|c|c|}
\hline \multirow[b]{2}{*}{$\begin{array}{l}\text { Plantation } \\
\text { pairwise }\end{array}$} & \multirow[b]{2}{*}{$\begin{array}{l}\text { Plantation age } \\
\text { (years) }\end{array}$} & \multicolumn{2}{|c|}{ High density ${ }^{\dagger \dagger}$} & \multicolumn{2}{|c|}{ Medium density ${ }^{\dagger}$} & \multirow[b]{2}{*}{ Macrozone } \\
\hline & & $\begin{array}{l}\text { Diameter at } \\
\text { breast height } \\
(\mathrm{cm})\end{array}$ & $\begin{array}{l}\text { Dominant } \\
\text { height }^{\dagger} \\
\text { (m) }\end{array}$ & $\begin{array}{l}\text { Diameter at } \\
\text { breast height } \\
(\mathrm{cm})\end{array}$ & $\begin{array}{l}\text { Dominant } \\
\text { height }^{\dagger} \\
\text { (m) }\end{array}$ & \\
\hline $1-2$ & 25 & $13.8 \pm 0.8$ & $6.0 \pm 0.0$ & $17.3 \pm 0.3$ & $7.8 \pm 0.1$ & Dry Coast \\
\hline $3-4$ & 26 & $16.9 \pm 0.7$ & $11.2 \pm 0.4$ & $20.2 \pm 0.4$ & $9.4 \pm 0.2$ & Dry Coast \\
\hline $5-6$ & 23 & $11.4 \pm 1.4$ & $5.1 \pm 0.0$ & $33.6 \pm 0.7$ & $14.6 \pm 0.2$ & Dry Coast \\
\hline $7-8$ & 25 & $10.3 \pm 0.8$ & $6.3 \pm 0.6$ & $25.7 \pm 0.5$ & $12.8 \pm 0.2$ & North \\
\hline $9-10$ & 30 & $14.1 \pm 0.9$ & $8.8 \pm 0.4$ & $37.1 \pm 2.0$ & $16.5 \pm 0.7$ & North \\
\hline $11-12$ & 30 & $21.8 \pm 1.3$ & $12.4 \pm 0.3$ & $32.9 \pm 1.1$ & $14.9 \pm 0.5$ & North \\
\hline $13-14$ & 35 & $30.9 \pm 1.9$ & $13.8 \pm 0.3$ & $30.7 \pm 1.1$ & $13.9 \pm 0.5$ & North \\
\hline $15-16$ & 25 & $8.5 \pm 0.7$ & $6.8 \pm 0.1$ & $27.4 \pm 0.5$ & $12.5 \pm 0.1$ & North \\
\hline $17-18$ & 23 & $15.8 \pm 1.6$ & $5.9 \pm 0.0$ & $37.0 \pm 1.7$ & $16.2 \pm 0.7$ & North \\
\hline $19-20$ & 50 & $44.2 \pm 1.7$ & $14.6 \pm 0.4$ & $54.0 \pm 3.2$ & $36.6 \pm 1.6$ & South \\
\hline $21-22$ & 12 & $21.9 \pm 0.6$ & $7.8 \pm 0.0$ & $21.3 \pm 1.4$ & $10.6 \pm 0.7$ & South \\
\hline $23-24$ & 40 & $55.2 \pm 0.9$ & $25.3 \pm 0.8$ & $38.5 \pm 2.9$ & $11.6 \pm 0.9$ & South \\
\hline $25-26$ & 17 & $23.6 \pm 1.4$ & $9.0 \pm 0.1$ & $24.0 \pm 1.7$ & $13.2 \pm 0.6$ & South \\
\hline $27-28$ & 50 & $40.6 \pm 1.3$ & $17.3 \pm 0.4$ & $82.6 \pm 1.9$ & $28.9 \pm 1.2$ & South \\
\hline $29-30$ & 50 & $44.1 \pm 1.6$ & $16.9 \pm 0.6$ & $62.3 \pm 3.6$ & $17.0 \pm 0.6$ & South \\
\hline
\end{tabular}

$\dagger$ Dominant height was obtained as the mean height of the 100 largest diameter trees per hectare (Soares et al. 2013) and is used as an expression of the site index. ${ }^{\dagger}$ Medium density: 500 trees ha ${ }^{-1}$, High density: 1,667 trees ha-1

Plot size for this study was determined by an average of 65 trees per plot, totaling 1,950 P. pinea trees. The climate of the North macrozone is characterized by the most challenging variables, with annual average temperature of $14.1^{\circ} \mathrm{C}$, annual maximum average temperature of $21.9^{\circ} \mathrm{C}$, thermal oscillation of $14.3{ }^{\circ} \mathrm{C}$, and annual rainfall of 383.7 $\mathrm{mm}$. In the South macrozone, the coldest and most humid one, climate is characterized by annual average temperature of $13.2^{\circ} \mathrm{C}$, annual maximum average temperature of $19.8^{\circ} \mathrm{C}$, thermal oscillation of $12.3{ }^{\circ} \mathrm{C}$, and annual rainfall of $1,047 \mathrm{~mm}$. The transition Dry Coast macrozone is characterized by intermediate values (average temperature $13.6{ }^{\circ} \mathrm{C}$, maximum average temperature $21.0{ }^{\circ} \mathrm{C}$; thermal oscillation $14{ }^{\circ} \mathrm{C}$; rainfall $648.3 \mathrm{~mm}$ ) (Lutz et al. 2017).

Statistical analyses. An ANOVA model including density, macrozone and plantation pair effects was fitted. The plantation age was used as covariate. Annual DBH and height growths as well as cone yield means were compared between densities using Fisher LSD test $(\alpha=0.05)$. Statistical analyses were performed using the software InfoStat (Di Rienzo et al. 2020) and their interface with R 3.5.3 (R Development Core Team 2019).

\section{RESULTS}

Average growth and cone yield for each planting density are presented in table 2. Plantations showed significant differences in DBH and height growth $(P<0.004$ and $P=$ 0.01 , respectively). The medium density resulted in $46 \%$ higher DBH growth and 2.8 times higher cone yield than in the high-density scheme. The macrozone effect was statistically significant for annual DBH growth $(P=0.004)$ and cone yield $(P<0.001)$. Because of the plantation pairing, plantation age was not significant for any of the variables (height, $P=0.273$; DBH, $P=0.228$; cone yield, $P=0.210)$.

Across macrozones (table 3), significant differences between densities were found for growth and cone yield in the North macrozone, and for cone yield in the North and South macrozones.

DBH and height growth, as well as cone yield, were negatively affected under the high-density scheme in the North macrozone, the one of highest annual average temperature and thermal oscillation, and lowest rainfall. In the South macrozone, in the medium density cone yield was 3.6 times higher than the high density. 
Table 2. Current annual growth rate and cone yield in Pinus pinea stands for each planting density.

Tasa de crecimiento corriente y producción de piñas en plantaciones de Pinus pinea según densidad.

\begin{tabular}{lcccr}
\hline \multicolumn{2}{c}{ Density } & $\begin{array}{c}\text { Diameter at breast height** } \\
\text { cm year }^{-1}\end{array}$ & $\begin{array}{c}\text { Height* } \\
\text { cm year }^{-1}\end{array}$ & $\begin{array}{r}\text { Cone yield* } \\
\text { cones ha }^{-1}\end{array}$ \\
\cline { 1 - 3 } High & 1,667 & $0.81 \pm 0.09 \mathrm{~b}$ & $34.8 \pm 0.5 \mathrm{~b}$ & $892 \pm 563 \mathrm{~b}$ \\
Medium & 500 & $1.18 \pm 0.09 \mathrm{a}$ & $51.0 \pm 0.5 \mathrm{a}$ & $2,511 \pm 563 \mathrm{a}$ \\
\hline
\end{tabular}

Average across 15 P. pinea plantations at high density and 15 plantations at medium density.

Mean \pm standard error. By column, same letter indicates non-statistical differences between densities.

$*=P<0.05 ; * *=P<0.01$.

Table 3. Annual growth rate per tree and cone yield in Pinus pinea plantations established at medium and high densities across macrozones.

Tasa de crecimiento anual y producción de piñas en plantaciones de Pinus pinea establecidas a densidad media y alta en diferentes macrozonas.

\begin{tabular}{|c|c|c|c|}
\hline Variable & Macrozone & $\begin{array}{l}\text { Medium density } \\
\left(500 \text { trees }^{-1}\right)\end{array}$ & $\begin{array}{l}\text { High density } \\
\left(1,667 \text { trees ha }^{-1}\right)\end{array}$ \\
\hline \multirow{3}{*}{$\begin{array}{l}\text { Annual average diameter at breast height growth } \\
\left(\mathrm{cm} \text { year-1 }^{-1}\right)\end{array}$} & North*** & $1.32 \pm 0.07 \mathrm{a}$ & $0.49 \pm 0.07 \mathrm{~b}$ \\
\hline & Dry Coast & $0.75 \pm 0.02 \mathrm{a}$ & $0.63 \pm 0.02 \mathrm{a}$ \\
\hline & South & $1.39 \pm 0.06 \mathrm{a}$ & $1.28 \pm 0.06 \mathrm{a}$ \\
\hline \multirow{3}{*}{$\begin{array}{l}\text { Annual average height growth } \\
\left(\mathrm{cm} \text { year }{ }^{-1}\right)\end{array}$} & North*** & $0.57 \pm 0.03 \mathrm{a}$ & $0.20 \pm 0.03 \mathrm{~b}$ \\
\hline & Dry Coast & $0.37 \pm 0.03 \mathrm{a}$ & $0.31 \pm 0.03 \mathrm{a}$ \\
\hline & South & $0.52 \pm 0.06 \mathrm{a}$ & $0.49 \pm 0.06 \mathrm{a}$ \\
\hline \multirow{3}{*}{ Cone yield (cones ha ${ }^{-1}$ ) } & North* & $739 \pm 185 a$ & $0 \pm 0 \mathrm{~b}$ \\
\hline & Dry Coast & $2,628 \pm 334 \mathrm{a}$ & $1,546 \pm 334 \mathrm{a}$ \\
\hline & South* & $3,997 \pm 1,118 \mathrm{a}$ & $1,096 \pm 1,118 b$ \\
\hline
\end{tabular}

Average across $P$. pinea plantations at high density and medium density by macrozone.

Mean \pm standard error. By row, same letter indicates non-statistical differences between densities.

$*=P<0.05 ; * * *=P<0.001$

\section{DISCUSSION}

Our results confirm our working hypothesis of a reduction of diameter growth and cone yield at the highest planting density, confirming the importance of silviculture in $P$. pinea crop development and cone yield. Both high and medium density levels tested in this study correspond to high and medium density levels used to establish P. pinea plantations in the species native habitat (Spain) (Montero 2004).

Cone and seed production in any given year are conditioned by vigor, health and size of trees (Calama and Montero 2007), especially by DBH (Moreno-Fernandez et al. 2013, Loewe et al. 2016). DBH and height growth of $P$. pinea trees was higher in the medium density plantation; Piqué et al. (2011) reported a similar effect of planting density on DBH growth.

Loewe and Delard (2016) found that high density plantations in Chile (1.5x1.5 to $3 \times 3 \mathrm{~m})$ induced excessi- ve height growth. In this study, the medium density also induced high height growth, evidencing that this density makes cone harvesting difficult. This is in agreement with findings reported by Correia et al. (2010) and Mutke et al. (2012), who stated that a density of 500 trees $\mathrm{ha}^{-1}$ is too high for the species, since it stimulates height growth.

The lowest planting density (500 trees ha- $\left.{ }^{-1}\right)$ induced a higher cone yield than that presented by the denser one $\left(1,667\right.$ trees ha $\left.^{-1}\right)$ in most of the species production area in Chile (North and South macrozones). This is in agreement with results of Calama et al. (2008) and Montero et al. (2008), who indicated that lower density stands in Spain yield larger fruit production than do stands of higher density. Similarly, pine nut production of Pinus resinosa Ait., a species comparable to $P$. pinea in its long fruit development cycle, was found to decrease at high stand density (Stiell 1971). A density of 400 trees ha ${ }^{-1}$ in seed orchards of Pinus sylvestris L., which is lower than the medium 
density here studied, was reported as appropriate for cone production (Jonsson et al. 1976).

Accordingly, medium to low densities ( $5 \times 5$ to $10 \times 10 \mathrm{~m})$ have been recommended to enhance cone production and facilitate harvesting (Costa and Evaristo 2008), allowing tree crown development and light interception (Piqué 2013). In fact, Boutheina et al. (2013) observed that bigger trees bear more cones, with crown development being more important in determining cone production than age, suggesting that spacing is an important factor to improve P. pinea cone yield. Loewe et al. (2019) also observed that a density of 204 trees ha ${ }^{-1}(7 \times 7 \mathrm{~m}$ spacing $)$ was associated with higher crown diameter and earlier and higher female strobili production than those presented by a 400 trees ha- ${ }^{-1}$ density $(5 \times 5 \mathrm{~m}$ spacing); both densities are within the most common ranges in new specialized plantations in Chile. This is in agreement with findings of Mutke et al. (2012), who reported that low density plantations ( 278 trees ha-1 or even less) have higher cone yield than that shown by high density plantations $\left(1,111\right.$ trees $\left.\mathrm{ha}^{-1}\right)$, allowing mechanical harvesting and tilling at the same time.

The impact of planting density on tree growth and cone yield in the North macrozone, the most arid and warm environment, would be caused by higher water availability to trees in the medium density plantations, since the water supply is shared by a lower number of trees, improving stand growth rates and cone yield, as reported by Mazza et al. (2011) and Gonçalves and Pommerening (2012); in fact, no cones were recorded in the high-density plantations in that macrozone. In the South macrozone, the coldest and most humid environment, the medium density increased cone yield 3.6 times compared to that from the high density, indicating that a wider spacing favors tree fruiting, even in less challenging hydric environments.

This study highlights the impact of planting density on tree growth, especially under arid and warm conditions. Stands growing at medium density may be benefited by less water deficit, improving plantation resilience under a climate change scenario. Considering the expected increases in frequency and duration of drought periods, especially in Mediterranean areas (Quintana-Seguí et al. 2016), our findings may help in the adoption of adequate silvicultural schemes in P. pinea plantations. Furthermore, cone yield in high-density plantations is lower than that observed in less dense ones. The fact that production is concentrated in fewer trees also implies a lower cost, higher harvest yield and higher profitability (Montero et al. 2008).

Considering that planting density is a key factor in cone yield, further controlled experimental studies on the effects of spacing on growth and cone yield are necessary to improve the species management in South America.

\section{CONCLUSIONS}

Our study confirms, in different environments of Chile, previous researches in native habitats with $P$. pinea re- lated to the influence of planting density on growth and cone yield. Cone yield negatively correlates with density; although, the lowest density studied (500 trees ha-1) is still too high to limit height growth, hindering cone harvest. In future research works, it would be important to identify the optimum planting density to enhance cone yield and facilitate harvest.

\section{ACKNOWLEDGEMENTS}

Measurements used for this article were funded by Fondo de Fomento al Desarrollo Científico Tecnológico (FONDEF), Comisión Nacional de Investigación Científica y Tecnológica (CONICYT), Chilean Ministry of Education (grant code D11I1134). The analyses were performed through the program "Advances for the use of high value forest and fruit-forest species for Chile" funded by the Chilean Ministry of Agriculture.

\section{REFERENCES}

Boutheina A, M Hedi El Aouni, P Balandier. 2013. Influence of stand and tree attributes and silviculture on cone and seed productions in forests of Pinus pinea L., in northern Tunisia. Options Méditerranéennes. Série A : Séminaires Méditerranéens 105: 9-14.

Calama R, J Gordo, S Mutke, G Montero. 2008. An empirical ecological-type model for predicting Stone pine (Pinus pi$n e a$ L.) cone production in the Northern Plateau (Spain). Forest Ecology and Management 255(3-4): 660-673. https://doi.org/10.1016/j.foreco.2007.09.079

Calama R, G Montero. 2007. Cone and seed production from Stone pine (Pinus pinea L.) stands in Central Range (Spain). European Journal of Forest Research 126(1): 2335. https://doi.org/10.1007/s10342-005-0100-8

Calama R, J Gordo, G Madrigal, S Mutke, M Conde, G Montero, M Pardos, M. 2016. Enhanced tools for predicting annual stone pine (Pinus pinea L.) cone production at tree and forest scale in Inner Spain. Forest Systems 5(3): e079. https:// doi.org/10.5424/fs/2016253-09671

Correia A, M Tomé, C Pacheco, S Faias, A Dias, J Freire, P Carvalho, J Pereira. 2010. Biomass allometry and carbon factors for a Mediterranean pine (Pinus pinea L.) in Portugal. Forest Systems 19(3): 418-433. https://doi.org/10.5424/ fs/2010193-9082

Costa R, I Evaristo. 2008. Conduçao de Povoamentos de Pinheiro Manso e caracteristicas Nutricionais do pinhao. In Costa R, I Evaristo eds. Lisboa, Portugal, Instituto Nacional dos Recursos Biologicos.

Di Rienzo JA, F Casanoves, M Balzarini, L Gonzalez, M Tablada, CW Robledo. 2020. InfoStat version 2020. Universidad Nacional de Córdoba, Argentina. Accessed 31 Jan. 2020. Available in http://www.infostat.com.ar

Gonçalves AC, A Pommerening. 2012. Spatial dynamics of cone production in Mediterranean climates: a case study of Pinus pinea L. in Portugal. Forest Ecology and Management 266: 83-93.

Jonsson A, I Ekberg, G Eriksson. 1976. Flowering in a seed orchard of Pinus sylvestris L. Studia forestalia Suecica 135. 
Loewe MV, M Balzarini, R Del Río, C Delard. 2019. Effects of stone pine (Pinus pinea L.) plantation spacing on initial growth and conelet entry into production. New Forests 50(3): 489-503. https://doi.org/10.1007/s11056-018-9672-2

Loewe MV, M Balzarini, C Delard, A Álvarez, RM NavarroCerrillo. 2017a. Growth of Stone pine (Pinus pinea L.) European provenances in central Chile. iForests 10: 64-69. https://doi.org/10.3832/ifor1984-009

Loewe MV, A Alvarez, M Balzarini, C Delard, RM NavarroCerrillo. 2017b. Mineral fertilization and irrigation effects on fruiting and growth in stone pine (Pinus pinea L.) crop. Fruits 72(5): 281-287. https://doi.org/10.17660/ $\underline{\text { th2017/72.5.3 }}$

Loewe MV, M Balzarini, A Álvarez, C Delard, RM Navarro-Cerrillo. 2016. Fruit productivity of Stone pine (Pinus pinea L.) along a climatic gradient in Chile. Agricultural and Forest Meteorology 223: 203-216. https://doi.org/10.1016/j. agrformet.2016.04.011

Loewe MV, C Delard, M Balzarini, A Álvarez, RM Navarro-Cerrillo. 2015. Impact of climate and management variables on stone pine (Pinus pinea L.) growing in Chile. Agricultural and Forest Meteorology 214-215: 106-116. https://doi. org/10.1016/j.agrformet.2015.08.248

Loewe MV, C Delard. 2016. Producción de piñón mediterráneo (Pinus pinea L.). Manual $N^{\circ}$ 48. Santiago, Chile. INFOR. $108 \mathrm{p}$.

Mazza G, E Amorini, A Cutini, M Manetti. 2011. The influence of thinning on rainfall interception by Pinus pinea $\mathrm{L}$. in Mediterranean coastal stands (Castel Fusano-Rome). Annals of Forest Science 68(8): 1323-1332. DOI: $10.1007 /$ s13595-011-0142-7

Montero G. 2004. El pino piñonero (Pinus pinea L.) en Andalucía: Ecología, Distribución y Selvicultura. Sevilla, Spain. Consejería de Medio Ambiente, Junta de Andalucía. 261 p.

Montero G, R Calama, R Ruiz. 2008. Selvicoltura de Pinus pinea L. In Montero G, R Serrada, J Reque eds. Compendio de selvicoltura de especies. Madrid, Spain. INIA-Fundación Conde del Valle de Salazar. p. 431-470.
Moreno-Fernández D, I Cañellas, R Calama, J Gordo, M Sánchez-González. 2013. Thinning increases cone production of Stone pine (Pinus pinea L.) stands in the Northern Plateau (Spain). Annals of Forest Science 70(8): 761-768. DOI: $10.1007 / \mathrm{s} 13595-013-0319-3$

Mutke S, R Calama, S González, G Montero, J Gordo, D Bono, L Gil. 2012. Mediterranean Stone Pine: Botany and Horticulture. In Janick J ed. Horticultural Reviews 39. Wiley-Blackwell. p. 153-201. https://doi.org/10.1002/9781118100592 . $\mathrm{ch} 4$

Pasalodos-Tato M, T Pukkala, R Calama, I Cañellas, M SánchezGonzález. 2016. Optimal management of Pinus pinea stands when cone and timber production are considered. European Journal of Forest Research 135(4): 607-619. DOI: $10.1007 / \mathrm{s} 10342-016-0958-7$

Piqué M. 2013. Gestion des forêts de pin parasol pour la production de pignons. Forêt Méditerranéenne 34(1): 59-62.

Piqué M, M Del-Rio, R Calama, G Montero. 2011. Modelling silviculture alternatives for managing Pinus pinea $\mathrm{L}$. forest in North-East Spain. Forest Systems 20(1): 3-20

Quintana-Seguí P, E Martin, E Sánchez, M Zribi, M Vennetier, S Vicente-Serrano, JP Vidal. 2016. Drought: observed trends, future projections. In Moatti J-P, S Thiébault eds. The Mediterranean Region Under Climate Change: A scientific update. Marseille, France. IRD Éditions. p. 123-131. https:// doi.org/10.4000/books.irdeditions. 23157

R Development Core Team. 2019. R: A language and environment for statistical computing. Vienna. R Foundation for Statistical Computing, Vienna. Accessed 31 Jul. 2019. Available in https://www.r-project.org/.

Soares JR, R Maestri, A Ferraz, J de Mello, A De Oliveira, A de Assis. 2013. Dominant height model for site classification of Eucalyptus grandis incorporating climatic variables. International Journal of Forest Research. https://doi. org/10.1155/2013/139236

Stiell W. 1971. Comparative cone production in young red pine planted at different spacings. Canadian Forestry Service 1306: 1-8. 